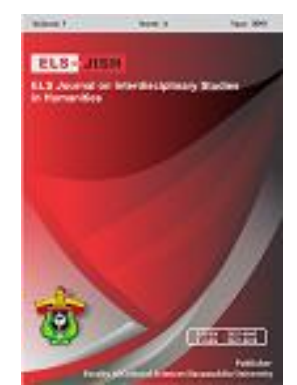

\title{
ELS-JISH
}

ELS Journal on Interdisciplinary Studies on Humanities

Volume 1 Issue 3, 2018

ISSN (print) : 2621-0843

ISSN (online) : 2621-0835

Homepage : http://journal.unhas.ac.id/index.php/jish

\section{The Washback Effect of Cat on Students' Learning in EFL Classroom}

\author{
Ida Dwi Safitri ${ }^{1}$
}

idadwisafitri@gmail.com

\begin{abstract}
This study explores how the students learn after CAT (computer-assisted test) is applied in teaching and learning English. CAT employs computer applications for evaluating test takers' performance in learning English. The main concern of this study is to investigate the washback effect of CAT on students' learning in EFL classroom in Indonesia. Washback itself is defined as the influence of the tests or assessments in teaching and learning. It means that washback effect indicates the critical role of the tests or assessments on students, teachers and societies. In a qualitative design, the findings show that there are washback effects of CAT on students' learning in EFL classroom.
\end{abstract}

Keywords: Computer-Assisted Test, Washback Effect, EFL, students' learning

How to cite: Safitri, I, D. (2018). The Washback Effect of Cat on Students' Learning in EFL Classroom. ELS Journal on Interdisciplinary Studies in Humanities, 1(3), 252-262.

\section{Introduction}

Harmer (2007) stated that English is spoken by the people around the world at least a quarter of the population. It is important to learn English because it can help to communicate with other people in abroad, to get some references in academic field and many other benefits. English is an international language that has to be learned by EFL (English as a foreign language) students from junior high school to university level. EFL here is described as "the situations where students were learning English in order to use it with any other English speakers in the world" (Harmer, 2007). The government realized that English is important to be held in EFL classroom activities because language, especially English, is hard to be learned without the understanding of it. To recognize the students' ability in mastering English, the EFL teacher has to give some test in order to get significant achievement. It is widely believed that testing influences teaching and learning in the fields of education and applied linguistics (Alderson and Wall, 1993).

Some experts believe that the influence or the effect of the test on teaching and learning is described as washback (Gates, 1995; Chen, 2002; Hughes, 2003; Brown, 2004; Cheng \& Curtis, 2004; Cheng, 2005). Based on Cheng and Curtis (2004) washback could be positive, negative, or no influence toward teaching and learning. The good result of testing that influences teaching practice is positive washback (Taylor, 2005). It means that teachers and learners have positive attitude towards the

\footnotetext{
${ }^{1}$ Sebelas Maret University
} 
tests. Meanwhile, the undesirable effect of the test in teaching and learning is defined as negative washback (Alderson and Wall, 1993). It means that the test does not give beneficial impact for teachers and students; it causes "the teacher or learner does not wish to teach or learn" (Alderson and Wall, 1993). Washback effect appears not only in the testing but also "in the teaching materials that teachers use" (Furaidah et al, 2015).

Nowadays, technology is very useful to be utilized in many areas especially in education. One of the usefulness is testing students using computer that is being the focus of this paper. Some scholars define that computer-assisted language testing is "tests that are administered at computer terminals or on personal computers" (Brown, 1997; Magdolna and Troy, 2012; Simin and Heidari, 2013). Pathan (2012) says that the use of computer-assisted language testing has been fascinating and has positive respond of language learners in the field of language teaching and learning.

The researchers realize that the washback effect of CAT on students' learning in EFL classroom is needed to be investigated. A research explored by Damankesh and Esmat Babaii (2015) reveal that washback effect has power to influence learners' learning and strategic behaviors. Moreover, a research conducted by Marzieh Rezaie and Mohammad Golshan (2015) explain that CAT makes the process of testing more innovative, flexible, individualized, efficient and fast. Thus, the researchers believe that this research is important to be conducted.

\section{Literature Review}

\subsection{Computer-assisted test in EFL classroom}

Computer-assisted language testing (CALT) or Computer-assisted test (CAT) is the test that administered using computer technology in the field of language assessment or language testing. Noijons (1994) reveals that CALT is "an integrated procedure in which language performance is elicited and assessed with the help of computer". Additionally, some experts explain that "the tests that are administered at computer terminals or on personal computers" is defined as computer-assisted language testing (Brown, 1997; Magdolna and Troy, 2012; Simin and Heidari, 2013).

According to Noijon (1994) and Pathan (2012) there are three processes of the use of computer technology, they are: generating the test, interaction with the candidate, and the evaluation of responses. The first procedure is generating the test. It means that the computer can follow the procedure; it can generate the tasks or select the test items from the item bank randomly. The second procedure relates to the interaction with the candidate. It means that the teacher can interact to the students even though the tests are taken using computer. It may arise some problems because it is relatively new process. The third procedure is the evaluation of responses. In this process, the computer can give the complete response data related to the test such as the time used, test takers' response, routing, and so on.

The types of the tests that are tested by the use of computer is receptiveresponse item such as multiple-choice, matching items, true-false, and so on. By the use of computer, there are five methods in collecting students' tasks (Weeden in Simin and Heidari, 2013) they are multiple-choice: selecting the correct answer from the list choice; ordering/ranking: list the answer into a correct answer; supplying: give short response to answer the task; locating: describing the picture given; and matching: match two lists of items. 
There are some advantages and disadvantages of computer-assisted test. Many scholar such as Madsen (1986, 1991), Dandonoli (1989), Larson (1989), Stansfield (1990), Chapelle and Dan Douglas (2006) have proposed the use of computer technology in the field of language testing and assessment. The major advantages of CAT are:

a. The burden of administrative and logistic can be overcome. There are many issues with the traditional testing practice such as the preparation of the test need long time to prepare; it may high cost if the tasks need to be printed out but if the question of the tasks are written down on the whiteboard or spoken up, it would take more time for the test takers in taking the test; it takes time in correcting the tasks and the corrector may not accurate in reporting. Meanwhile, the use of computer in testing, the time in preparation, test taking, correcting, and so on are less consuming time. Additionally, computer is more accurate at scoring and reporting.

b. It offers consistency. The tasks or information given to the test takers have the same materials or instructions even though the questions of the test are randomized.

c. It enhances the interaction between test taker's communicative language ability and the test tasks. Moreover, it also can enhance the authenticity of the test.

d. CAT gives understanding related to the test takers' strategies in taking the tasks. Alderson and Wall (1993) views that "the computer has the ability to measure time. The time which a learner takes to complete a task or even the time taken on different parts of a task can be measured, controlled and recorded by computer." By knowing this situation, it makes the test takers to make strategies in preparing and taking the tasks. The test takers also can prepare the strategies in learning English in order to pass the test.

e. Individualizes. It means that in taking the tasks by the use of computer, the test takers would have difficulty in cheating because the questions of the tasks are randomized. It encourages the students to do the test individually.

f. CAT can provide test result and feedback. The computer can provide the result of the test or can give score accurately and immediately. The teacher also can give feedback that would be shown in the beginning, middle or last of the task if it is needed.

g. CAT needs less time to finish compare to the traditional test. It is in line with the research conducted by many researchers such as Madsen, 1991; Kaya-Carton et al, 1991; and Laurier, 1999 state that computer-assisted tests require less time in taking the than the traditional paper-pencil tests.

h. CAT enhances positive attitude. According to a research conducted by Madsen (1986) more than $81 \%$ test takers who take the test by the use of computer expressed a more positive attitude toward CALT than when the students took the test using paper-and-pencil.

There are some disadvantages of CAT (Magdolna and Troy, 2012; Simin et al, 2013), they are:

a. The implementation of CAT can be high cost because each students need to use the computer and it is consuming high electricity. 
b. Time consuming. The teacher has to prepare the material, integrate with the school, and the students need to go to the laboratory in order to conduct the CAT.

c. Sometimes, in unpredictable moment, the computer may be not working as expected.

d. The limitation of computer screen. For example when conducted reading test that has long passages, the screen of the computer is limited. The students have to scroll the text up and down in order to read the whole of the text.

e. Students need to have experience in using computer in order to avoid the anxiety of computer. Some students can be familiar using computer and the other unfamiliar used it. It influences their performances in doing the test by the use of computer.

f. The anonymous marking cannot be implemented by some system. For example, the bold, italic or underline words do not appear in CAT. The examiner needs to change the question or mention the intended word in order to make the question readable.

g. Cheating will arise. Even though the students who take the test by the use of computer have difficulty in cheating because the questions are organized randomly, the lazy students will do anything in order to finish the test.

\subsection{Washback effect}

According to many researchers (Gates, 1995; Chen, 2002; Hughes, 2003; Brown, 2004; Cheng \& Curtis, 2004; Cheng, 2005) washback or backwash effect is the influences of the tests or assessment on teaching and learning. It means that testing effect teaching and learning (Alderson and Wall, 1993). Based on the Saif's (2006) point of view washback is the influence of testing, assessment, and assessment procedures on teaching, learning, classroom activities and course content.

The tests not only affect teaching and learning activities but also curriculum, teaching methods, students' learning strategies, and so on (Biggs, 1995). Moreover, the influences that are found out working in washback are "public examinations influence the attitudes, behaviors, and motivation of teachers, learners and parents" (Pearson, 1988). Bailey (1996) declares some opinions concerning washback, they are: washback is the effect of test on teaching and learning; the tests that should propel learning activity is the concept of 'measurement-driven instruction'; curriculum focuses on the relationship between testing and syllabus; the tests are integrated into the educational system by systemic validity.

Washback effect in the field of language is the tests that affect language of the teachers and learners whether it can promote or inhibit language teaching and learning (Messick, 1996). According to Watanabe (2004) washback in teaching is the influence of the tests toward teacher's knowledge, beliefs, and training. It means that in teaching activities the processes of the tests that influence teacher are not simple. In other hand, the washback effect of the tests on learning is also not a simple process; it is a complex process that is influenced by contextual and learner-related factors (Cheng, 2005; Green, 2013). 
Washback effect is classified into neutral, positive and negative (Dorobat, 2007). Neutral washback means that the tests do not have influence toward teaching and learning. Positive washback is the benefit effect of tests, assessments, or examinations in teaching and learning (Alderson and Wall, 1993). It means that positive washback occurs when the tests have beneficial effect on educational practice (Hughes, 2003). Additionally, positive washback is the tests that have good result that encourage teaching and learning practices (Taylor, 2005).

Negative washback, according to Bailey (1996), is the contrary between the standardized of the tests and the principles and practices of communicative language teaching. It means that the materials given to the students are different to the tasks that are tested; it makes the negative washback occurs on teaching and learning activities. Additionally, Cheng and Curtis (2004) states that negative washback is the tests that have negative influence on teaching and learning. The tests do not have beneficial effects towards teaching and learning activities for example the students do not want to learn or the teachers do not wish to teach (Alderson and Wall, 1993). The areas that are influenced by washback are materials, curriculum, learning, teaching strategies, feelings and attitudes, and teaching contents (Pizarro, 2009).

\section{Methods}

\section{Context}

The aim of this study is to investigate the effects of CAT on the students' learning who take the test for various academic purposes. The researchers conducted this study in SMA N 2 Surakarta, Central Java, Indonesia in academic year 2018 that the English teacher has been implementing CAT as the classroom test in exercising students' knowledge of academic English. It was rarely found the English teachers who conducted CAT in testing students' English ability. Most of them still used traditional testing such as paper pencil test. There were some teachers who utilized CAT in testing students, but only an English teacher who applied it.

The incentive behind the application of CAT was that the teacher realized that the students in Indonesia need to take CAT or also known as CBT (computer-based test) in order to pass the national examination that should be taken by twelfth graders. It encouraged the teacher to apply CAT earlier, in eleventh grade, in order to prepare the students facing the national examination in the future. Taking the test using computer is not cheap. The cost of the computer itself and the electricity are quite expensive. The teacher explained that by applying CAT the students were expected to overcome their anxiety in taking test using computer and meet their need in learning English.

\section{Participants}

The participants of this study were the students of eleventh grade students of SMA N 2 Surakarta at class XI IPS 5 in the academic year of 2018/2019 with the average age of sixteen years old. Ten students were asked to participate in this research but only four students agreed to contribute as a participant. An English teacher was asked to participate in this study. There were four English teachers in this school but only an English teacher who applied CAT in classroom testing; the other teachers who applied CAT did not teach English major. The teacher has more than 15 years' experiences in teaching English. The meeting of the English class was for 90 minutes twice a week. 


\section{Research objective}

The aim of this research study was to investigate the possible negative, neutral and positive washback effects of CAT on students' learning in EFL classroom.

\section{Data collection}

The aim of this study is to investigate the washback effect of CAT on students' learning in EFL classroom. A qualitative method is used in this study. It is in line to the research conducted by Cheng and Curtis (2004) that informs that qualitative inquiry is suggested by the washback researchers in analyzing washback effect of a given test. The researchers applied a case study as the strategy of this study in order to collect the information of the washback effect of CAT on students' learning in EFL classroom. All the data were collected merely from interview that the data were derived based on teacher and students' point of view which are based on personal experience, feedback and reflection.

\section{Data analysis}

Constant comparative analysis is used to collect the data through semistructured interviews (Glaser \& Strauss, 1967). The process is sifting the repeated data in order to distinguish the patterns and similarities of interviews that have been transcript. The process was continued until found out the understanding of the data.

\section{Findings and Discussion}

The finding revealed that CAT has positive and negative washback effect. The description of each issue is as follows:

\subsection{The Positive Washback of CAT on Students' Learning}

Computer-assisted test sometimes used by the teacher to test students' academic English skill and knowledge. The positive washback of CAT occurred on both student and teacher but this research focus on students' learning. The positive influence of CAT on students, based on students' point of view, they were more enthusiastic in taking the test and in learning English. The students explained that in some aspect taking test using computer is easier than paper based test. They only needed to click the correct answer of the task which was given. They could monitor which question that had been answered and had not been answered by them. When the students confused or hesitated, they could give mark to the box of number that showed in the left of the monitor. After finished the task, they could directly see the score and got feedback from the teacher if it was added. In addition, computerized marking is more accurate than human beings.

The CAT prepared by the English teacher was challenging that focused on reading, grammar, and vocabulary. The teacher utilized speaker and projector in testing listening; the students were given answer sheet then listened to the question and answered the blank word. In testing students' writing, sometimes the teacher used CAT when the question given needed short answer. When the students asked to make some paragraphs or needed to write down many words, the teacher still applied traditional testing such as paper-pencil test. Unfortunately, CAT could not be used to testing students' speaking. In testing or assessing speaking, the teacher asked the students to speak directly in front of the class, retelling story, debate, or presentation. 
Based on the interview that was conducted by the researchers, the students described that the learning processes were more enjoyable. The teacher delivered the material not only used textbook but also computer, projector, mobile phone and so on. It made the students learn English through various and meaningful learning tool that encouraged students to meet their need in learning English. It made the students change or improve their strategy in learning. Before taking the test, the teacher announced that they would take the test by the use of computer of traditional paper-pencil test. It gave the students to learn before conducting the test.

The students explained that taking the test by the use of computer was different to paper-pencil test. It encouraged them to change their strategy in learning because when CAT was conducted, the tasks were concerning to reading, vocabulary and grammar. Some of the students who changed their strategies in learning explained that in taking test about reading, vocabulary and grammar they needed to memorize and understand the materials for example the students who focused on listening and speaking as the strategies in learning English had to change their strategies in order to pass the test. The students who were confidence to their learning did not change their strategies. They believed that they needed to improve their learning, in other word they should learn harder, in order to get good achievement even though they did not change their learning strategies. Additionally, CAT motivated the students to learn more. They believed that taking the test by the use of computer would have benefit in academic purposes especially to face the national examination that conducting CAT in the future.

According to teacher's point of view, the influence of CAT on students was that the students were more enthusiastic in taking test and motivated in learning process. Students were encouraged to be more active to meet their learning need. The teacher believed that some students changed their learning strategies, improving their strategy in learning, and some of them did not change or improve their learning strategy. The students who changed their strategies

The recent national examination, which applying computer-assisted test or as known as computer-based test, has motivated the teacher to apply CAT in his class. The teacher explained that the students had to acquaint CAT as soon as possible in order to minimalize computer anxiety. When applying CAT at the first time, the teacher confessed that there was dissimilarity between the students who had been familiar and unfamiliar in taking the test by the use of computer. The students who had been familiar to CAT took the test smoothly, while the students who had been unfamiliar felt difficulty in taking the test. Moreover, CAT reduced students' opportunity in cheating, because the questions were organized randomly. Besides, it encouraged the teacher to enhance his creativity in teaching.

Based on the investigation above, it can be concluded that the positive washback of CAT on students' learning in EFL classroom occurred on students' learning attitudes, activities, strategies and motivations. It proves that computerassisted test influences students' learning positively.

\subsection{The Negative Washback of CAT on Students' Learning}

Besides the positive washback, CAT has negative washback on students' learning. Based on the students' point of view, the negative washback of CAT on EFL classroom occurred when the computer which was used by student error, it influenced students' mood in doing the task. The enthusiastic in taking CAT was 
decline because the time kept going whereas they had to submit the test on time. For example, the test was set in thirty minutes, then the students had to submit it on time; it would be submitted automatically if the students' did not submit it on time. The time given could not be added because the system had already set on time.

Additionally, the students who did not familiar using computer felt anxiety when used it. The students confused to take the test by the use of computer. They did the test cautiously to avoid the mistake in taking the test. It took longer time or spent their time to do the test and sometimes the time was up before the students finished the test. The students who failed in taking the test did not have interest in learning English. It reduced their motivation to learn English. CAT made the students stress and thinking too much about their future.

According to teacher's point of view, the negative influence raised when the student with low motivation in learning English did not interest in taking CAT. The teacher explained that the opportunity in cheating still appeared but it was lower than that of when they were tested using paper pencil test. The technical malfunction was the general reason that appeared in applying CAT and it decreased students' mood in taking the test when it happened.

The preparation of the test was more complicated preparation than paper pencil test. In traditional test, the teacher could read, write on the white board, or print out the question. Meanwhile, when the teacher applied CAT, after typed the question in the computer, the teacher gave it to the technician in order to input the data and regulate it to be CAT. In this step, the teacher could ask the technician control the condition of the test such as the duration, arrange the question randomly, give feedback, whether the students could see the score or not, and etc.

Based on the explanations above it can be concluded that negative washback of CAT on students' learning in EFL classroom occurred on students' learning attitude, activity, and motivation. It means that, besides affecting the students' learning positively, CAT influences students' learning negatively.

\section{Conclusion}

Based on the result, CAT has powerful effect on students' learning in EFL classroom. The washback effect of CAT has both positive and negative washback. The positive washback occurs on students' learning attitudes, activities, strategies and motivations, such as: the students are more enthusiastic in taking the test, increase students' motivation in learning English, the learning process are more enjoyable, reduces the opportunity in cheating, increase teacher's creativity in teaching and so on. While the negative washback of CAT in EFL classroom occurs on students' learning attitude, activity, and motivation, they are: the lack of student's enthusiastic in doing the test when the computer get error, computer anxiety, the opportunity of cheating in teaching still arise, the preparation is more complicated than paper pencil test, and so on.

In short, this research provides a clear evidence of the washback effect of the computer-assisted test on students' learning in teaching and learning process in English as a foreign language classroom. The findings of this research are unique; it can be a consideration to the teachers who want to apply CAT in their class whether they need to use CAT or not in language testing. Additionally, the perceptions and practices of the teacher play a vital role in teaching and learning process in the classroom. Finally, it could be stated that this research enhances the researchers' 
ISSN: (E) 2621-0835, (P) 2621-0843

knowledge and hopefully the other researchers could investigate further study on washback phenomenon in Indonesia context.

\section{References}

Alderson, J. C., \& Wall, D. (1993). Does washback exist? Applied Linguistics, 14(2), 115-129. http://dx.doi.org/10.1093/applin/14.2.115.

Babaii, Esmat. \& Damankesh, Meysam. (2015). The washback effect of Iranian high school final examination on students' test-taking and test-preparation strategies. Studies in Educational Evaluation. ELSEVIER Journal. 62-69.

Bailey, K. M. (1996). Working for washback: A review of the washback concept in language testing. Language Testing, 13(3), 257-279.

Biggs, J. B. (1995). Assumptions underlying new approaches to educational assessment. Curriculum Forum, 4(2), 1-22.

Brown, D. H. (2004). Language Assessment: Principles and Classroom Practices. San Fransisco. Longman: Pearson Education.

Brown, J.D. (1997). Computers in language testing; Present research and some future directions. Language Learning and Technology, Vol. 1, No. 1, pp.4459.

Carol A. Chapelle and Dan Douglas (2006) Assessing language through computer technology Cambridge: Cambridge University Press.

Chen, L. (2002). Washback of a public exam on English teaching. ERIC Document Reproduction Service No. ED472167.

Cheng, L. (2005). Changing language teaching through language testing: $A$ washback study. Studies in language testing, 21. Cambridge: Cambridge University Press.

Cheng, L. and A. Curtis. (2004). Washback or backwash: A review of the impact of testing on teaching and learning. In Washback in language testing: Research contexts and methods, eds. L. Cheng, and Y. Watanabe, A. Curtis, 3-18. Mahwah, New Jersey: Lawrence Erlbaum Associates.

Dandonoli, P. (1989). "The ACTFL Computerized Adaptive Test of Foreign Language Reading Proficiency." Modern Technology in Foreign Language Education: Application and Projects, edited by F. Smith. Lincolnwood, IL: National Textbook.

Dorobat, Dumitru. (2007). The Methodology of Evaluation and Testing. Ministerul Educatiei si Cercetarii. Proiectul pentru Invatamantul Rural.

Furaidah. Saukah, Ali. Widiati, Utami. (2015). Washback of English National Examination in the Indonesian Context. TEFLIN journal, Volume 26, Number 1, January 2015, pp. 36-58. Universitas Negeri Malang.

Gates, S. (1995). Exploiting washback from standardized tests. In J. D. Brown, \& S. O. Yamashita (Eds.), Language testing in Japan (pp. 101-106). Tokyo: Japanese Association for Language Teaching.

Glaser, B. G., \& Strauss, A. L. (1967). The discovery of grounded theory. New York: Aldine. (101-116). 
Golshan, Mohammad. Rezaie, Marzieh. (2015). Computer Adaptive Test (CAT): Advantages and Limitations. International Journal of Educational Investigations. Vol.2, No.5: 128-137, 2015.

Green Antoni. (2013). Washback in Language Assessment. International Journal of English Studies. IJES, vol. 13 (2), 2013, pp. 39-51. University of Murcia.

Harmer, Jeremy. (2007). The Practice of English Language Teaching. Pearson Education Limited.

Hughes, A. (2003). Testing for language teachers (2nd ed.) Cmbridge: Cambridge University Press.

Kaya-Carton, E., Carton, A. S. \& Dandonoli, P (1991). Developing a computeradaptive test of French reading proficiency. In P. Dunkel (ed.), Computerassisted language learning and testing: Research issues and practice ( $p p$. 259-84) New York: Newbury House.

Larson, J. W. \& Madsen. H. S. (1989). "S-CAPE: A Spanish Computerized Adaptive Placement Exam." Modern Technology in Foreign Language Education: Application and Projects, edited by F. Smith. Lincolnwood, IL: National Textbook.

Laurier, M. (1999). The development of an adaptive test for placement in French. In M. Chalhoub-Deville (ed.), Development and research in computer adaptive language Testing (pp. 122-35). Cambridge: University of Cambridge Examinations Syndicate/Cambridge University Press.

Madsen, H. S. (1986). Evaluating a computer adaptive ESL placement test. CALICO Journal 4, 41-50.

Madsen, H. S. (1991). Computer-adaptive testing of listening and reading comprehension: the Brigham young approach. In P Dunkel (ed.), Computerassisted language learning and testing: Research issues and practice (pp. 237-257). New York: Newbury House.

Magdolna, F. Silye., \& Troy B. Wiwczaroski. (2012). A critical review of selected computer assisted language testing instuments. University of Debrecen. Centre of Technical Language Instruction, Debrecen.

Messick, S. (1996). Validity and washback in language testing. Language Testing, 13(3), 241-256.

Noijons, J. (1994). Testing computer assisted language tests: Towards a checklist for CALT. CALICO Journal, 12(1), 37-58.

Pathan, Mustafa Mubarok. (2012). Computer Assisted Language Testing (CALT): Advantages, Implication and Limitations. The University of Sebha, Sebha, Libya. Vol. 1. Issue 04.

Pearson, I. (1988). Tests as levers for change. In D. Chamberlain \& R. J. Baumgardner (Eds.), ESP in the classroom: Practice and evaluation (pp. 98-107). London: Modern English.

Pizarro, M. A. (2009). Does the English teaching in the Spanish university entrance examination influence the teaching of English? English Studies, 90(5), 582598. 
ISSN: (E) 2621-0835, (P) 2621-0843

Saif, S. (2006). Aiming for positive washback: a case study of international teaching assistants, Language Testing Journal, 23 (1), pp.1-34.

Simin, Shahla., \& Heidari, Afrooz. (2013). Computer-based assessment: pros and cons. Educational Technology. Elixir Edu. Tech. 55 (2013) 12732-12734.

Stansfield, C. (ed.) (1986). Technology and language testing. Washington DC: TESOL Publications.

Taylor, Linda. 2005. Washback and impact. Oxford Journal: Art and Humanities: English Language Teaching Journal, 59(2): 154-155.

Watanabe, Y. (2004). Teacher factors mediating washback. In L. Cheng, Y. Watanabe, \& A. Curtis (Eds.), Washback in language testing: Research contexts and methods (pp. 129-146). Hilsdale, NJ: Lawrence Erlbaum. 